\title{
POMEGRANATE WONDERFUL CULTIVAR MICROCLONAL PROPAGATION TECHNOLOGY IN VITRO
}

\author{
Ochildiyev Jakhongir Mengdobilovich ${ }^{1}$, \\ Saimnazarov Yuldash Bekmirzaevich ${ }^{2}$ \\ ${ }^{I}$ PhD Student, Scientific-Research Institute for Horticulture, Viticulture and Winemaking Under the \\ name of Academician M.Mirzayev \\ ${ }^{2}$ Doctor of Biological Sciences, Professor, Tashkent State Agrarian University \\ 111116, str. Chimkent, Gulistan, Tashkent District, Tashkent Region, Uzbekistan
}

Article DOI: https://doi.org/10.36713/epra8997

DOI No: 10.36713/epra8997

\begin{abstract}
Introduced in the article, the Wonderful variety of pomegranate was studied in vitro for microclonal propagation, sterilization at 1.0 and $3.0 \%$ solution of sodium hypochlorite $(\mathrm{NaOCl})$ at different times, swelling of the variety in different nutrient media, the percentage of germination. The subculture process under the influence of nutrient media hormones $B A P, K i n, I B A$ and $G A_{3}$ and the results of pomegranate rooting are covered.
\end{abstract}

\section{INTRODUCTION}

Subtropical fruits are important with their unique agroecological and technological properties. In Uzbekistan, pomegranate is the leading subtropical crop, with $25 \%$ of pomegranates growing. Pomegranate fruits have long been widely used in the national economy and are used as a remedy for a hundred ailments $[2,5]$.

It is important to use the method of microclonal propagation of seeded and seedless varieties of introduced pomegranate, selection of the optimal nutrient medium for tissue growth, proper sterilization, rooting of young shoots, transplantation of plants to nosteril conditions in laboratory (in vitro) and greenhouse (in vivo). is a scientific-practical and topical issue $[1,3,4]$.

Another advantage of in-vitro pomegranate propagation is that it has a very high reproductive capacity and it is important to grow thousands of clone seedlings in vitro at a time when there are many problems in growing seedlings in the traditional way.

\section{MATERIALS AND METHODS}

The Wonderful variety of pomegranate, which was introduced into the study, was sampled in 2019 from a maternal garden imported from the Italian state. The variety was prepared for microclonal propagation in the laboratory of "Biotechnology" of the institute. Branched twigs were sterilized in sodium hypochlorite solution. Sterilized samples were washed 3-4 times in clean water distilled in an autoclave at a temperature of + $121{ }^{\circ} \mathrm{C}$ to remove all chemical residues used in sterilization.

Conditions of cultivation. The dishes were carried out in an incubator at $58 \pm$ lux at $23 \pm 1$ oC under photoperiodic conditions for 16 hours. The experiments were performed in 4 different variants and 3 repetitions.

Nutrient environment. Microorganisms were treated with $10 \mathrm{ml}$ MS (Murashige and Skoog, 1962) nutrient media in $100 \mathrm{ml}$ test tubes. BAR with different content and concentrations in the nutrient medium was placed in an environment with IBA 
supplements. The $\mathrm{pH}$ of the nutrient medium was set to 5.8 and was controlled by 1 normal $\mathrm{HCl}$ and $\mathrm{KOH}$.

\section{RESULTS AND DISCUSSION}

The first and foremost step in microclonal propagation in vitro is the introduction of these implants into the culture. But the result is a process that is directly related to the surface sterilization of new plant materials, i.e. implants.

For surface sterilization of Wonderful variety of pomegranate, 1.0 and $3.0 \%$ solutions of sodium hypochlorite were used.

In surface sterilization of the Wonderful variety of pomegranate, the number of buds introduced into the culture during sterilization for 15 minutes in $1.0 \% \mathrm{NaOCl}$ solution was 30 , the number of damaged buds was $69.9 \%$, and the number of surviving buds was $30.1 \%$.

When the Wonderful variety was sterilized for 10 minutes in $1.0 \% \mathrm{NaOCl}$ solution, the number of buds introduced into the culture was 30 , the number of damaged buds was $21.7 \%$, the number of surviving buds was $78.3 \%$, and the number of damaged buds was $48.2 \%$ less than the control. The buds recorded a high rate of $48.2 \%$ (Table 1 ).

The most inefficient indicator of surface sterilization of Wonderful variety was the number of buds introduced into the culture when sterilized for 20 minutes in a $1.0 \%$ solution of sodium hypochlorite, the number of damaged buds was $74.1 \%$, and the number of surviving buds was $25.9 \%$.

Table 1

Surface sterilization of Wonderful cultivars of pomegranate in vitro, 2020-2021

\begin{tabular}{|c|c|c|c|c|}
\hline $\begin{array}{c}\text { Surface sterilization } \\
\text { agent and } \\
\text { concentration }\end{array}$ & $\begin{array}{c}\text { Sterilization } \\
\text { time, } \\
\text { minutes }\end{array}$ & $\begin{array}{c}\text { Number of buds } \\
\text { included in the } \\
\text { culture, pcs }\end{array}$ & $\begin{array}{c}\text { Damaged } \\
\text { buds, } \\
\mathbf{\%}\end{array}$ & $\begin{array}{c}\text { Surviving buds, } \\
\mathbf{\%}\end{array}$ \\
\hline \multirow{4}{*}{$\mathrm{NaOCl}-1,0 \%$} & 5 & 30 & 47,5 & 52,5 \\
\cline { 2 - 5 } & $\mathbf{1 0}$ & $\mathbf{3 0}$ & $\mathbf{2 1 , 7}$ & $\mathbf{7 8 , 3}$ \\
\cline { 2 - 5 } & $15 \mathrm{control}$ & 30 & 69,9 & 30,1 \\
\cline { 2 - 5 } & 20 & 30 & 74,1 & 25,9 \\
\cline { 2 - 5 } $\mathrm{NaOCl}-3,0 \%$ & 5 & 30 & 53,2 & 46,8 \\
\cline { 2 - 5 } & $\mathbf{1 0}$ & $\mathbf{3 0}$ & $\mathbf{3 4 , 6}$ & $\mathbf{6 5 , 4}$ \\
\cline { 2 - 5 } & 15 & 30 & 73,3 & 26,7 \\
\hline
\end{tabular}

When the Wonderful variety of pomegranate was sterilized for 10 minutes in a $3.0 \% \mathrm{NaOCl}$ solution, the number of buds introduced into the culture was 30, the number of damaged buds was $34.6 \%$, and the number of surviving buds was $65.4 \%$.

In different nutrient media, BAP (benzyl amino purine), Kin (kinetin) and $\mathrm{GA}_{3}$ (Gibberillin acid) - 05, and $1.0 \mathrm{mg} / \mathrm{l}$ of growth-regulating substances under the influence of pomegranate Wonderful cultivar implants were found to have germination and germination percentage.

Mortality in the Wonderful cultivar MS (Murashige and Skoog, 1962) was observed for 3840 days without exposure to the growth medium in the controlled nutrient medium, and the degree of germination was not observed (Table 2).
Oral edema DKW (Driver and Kuniyuki, 1984 ) in the culture medium BAP-1.0 $\mathrm{ml} / 1$ and $\mathrm{GA}_{3}$ - $0.2 \mathrm{mg} / 1$ under the influence of 13-15 days, and apicality $65.9 \%$, compared to the control variant 25 days early edema was noted and the morbidity rate was reported to be $65.9 \%$ higher.

Swelling of the WPM (Woddy Plant Medium) nutrient medium under the influence of BAP $-1.0 \mathrm{mg} / 1$ and $\mathrm{GA}_{3}-0.2 \mathrm{mg} / 1$ was $16-18$ days and the rate of swelling was $48.9 \%, 22$ days earlier than the control variant. apostasy was observed and the apathy rate was observed to be $48.9 \%$ higher.

The most effective germination and germination percentage for the Wonderful variety of pomegranate was under the influence of BAP-1.0 ml / 1 and GA3-0.2 $\mathrm{mg} / 1$ in the DKW nutrient medium, with a germination rate of $65.9 \%$. 
SJIF Impact Factor 2021: 8.013| ISI I.F.Value:1.241| Journal DOI: 10.36713/epra2016 ISSN: 2455-7838(Online) EPRA International Journal of Research and Development (IJRD)

Table 2

Influence of different composition and concentration of growing substances on the germination of Wonderful variety of pomegranate, 2020-2021.

\begin{tabular}{|c|c|c|c|c|c|}
\hline \multirow[t]{2}{*}{$\begin{array}{c}\text { Feeding } \\
\text { environments }\end{array}$} & \multicolumn{3}{|c|}{$\begin{array}{c}\text { Growing agents, } \\
\text { mg / l }\end{array}$} & \multirow[t]{2}{*}{ bud growth, day } & \multirow[t]{2}{*}{ bud growth,, \% } \\
\hline & BAP & Kin & $\mathbf{G A}_{3}$ & & \\
\hline \multirow[t]{5}{*}{ MS (control) } & - & - & - & $38-40$ & - \\
\hline & - & - & - & $38-42$ & - \\
\hline & - & - & - & - & - \\
\hline & - & - & - & $40-43$ & - \\
\hline & - & - & - & $40-43$ & - \\
\hline \multirow[t]{5}{*}{ DKW } & 1,0 & - & 0,2 & $13-15$ & 65,9 \\
\hline & - & - & 0,5 & $20-22$ & 2,6 \\
\hline & 0,3 & 1,0 & - & $17-19$ & 41,6 \\
\hline & - & 0,5 & 1,0 & $19-21$ & 29,2 \\
\hline & 0,5 & - & 0,5 & $16-19$ & 35,7 \\
\hline \multirow[t]{5}{*}{ WPM } & 1,0 & - & 0,2 & $16-18$ & 48,9 \\
\hline & - & - & 0,5 & $21-25$ & 1,7 \\
\hline & 0,3 & 1,0 & - & $17-20$ & 43,6 \\
\hline & - & 0,5 & 1,0 & $19-23$ & 23,8 \\
\hline & 0,5 & - & 0,5 & $19-23$ & 30,5 \\
\hline
\end{tabular}

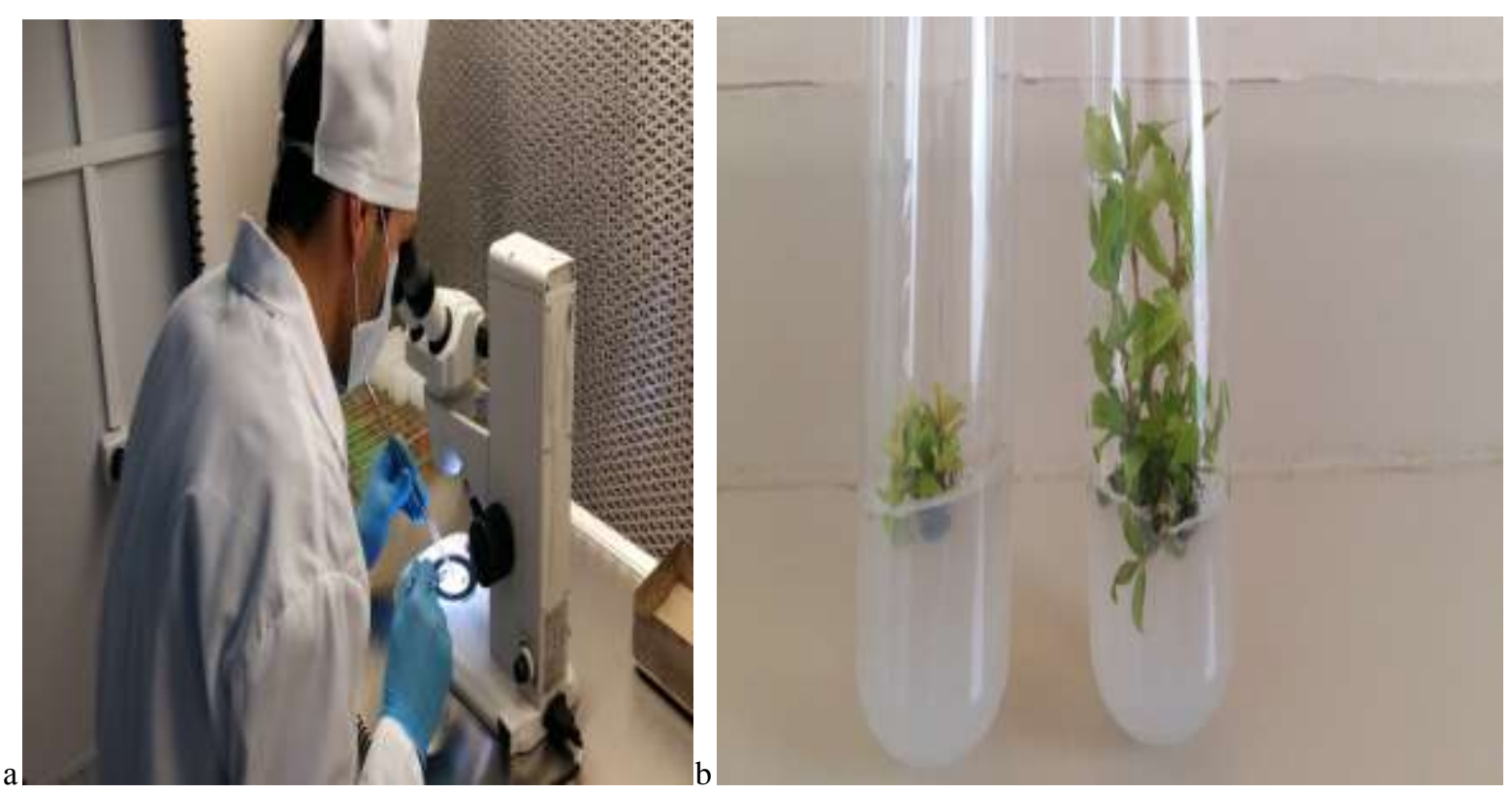

Figure 1. Cultivation of pomegranate varieties (a) and the process of germination (b)

A low rate of germination was observed in the control and WPM nutrient medium GA3-0.2 mg / 1 , the germination rate was 21-25 days, and the germination rate was $1.7 \%$ (Table 3 and Figure 1).

For good growth of pomegranate microplants that were cultured in different nutrient media, re-culturing (subc

ulture) was carried out by transplanting them to a new nutrient medium four times every 21 days. In re-cultivation, the rate of reproduction of micro-plants, horn length, number of leaves and percentage of rooting were calculated. 
Table 3

Influence of nutrient media on re-culturing (subculture) of Pomegranate Wonderful variety, 2020-2021.

\begin{tabular}{|c|c|c|c|c|c|}
\hline $\begin{array}{c}\text { Feeding } \\
\text { environments }\end{array}$ & Planting process & $\begin{array}{c}\text { reproduction } \\
\text { rate }\end{array}$ & horn length, cm & $\begin{array}{l}\text { number of } \\
\text { leaves, pcs }\end{array}$ & take root, \% \\
\hline \multirow[t]{4}{*}{ MS (control) } & I re - culture & $1: 2$ & 2,4 & 5 & 0 \\
\hline & II re - culture & $1: 4$ & 3,9 & 7 & 0 \\
\hline & III re - culture & $1: 8$ & 6,0 & 10 & 0,7 \\
\hline & IV re - culture & $1: 9$ & 6,8 & 12 & 0,7 \\
\hline \multirow[t]{4}{*}{ DKW } & I re - culture & $1: 4$ & 4,9 & 7 & 10,0 \\
\hline & II re - culture & $1: 6$ & 11,6 & 9 & 23,6 \\
\hline & III re - culture & $1: 10$ & 12,3 & 11 & 78,3 \\
\hline & IV re - culture & 1:12 & 13,5 & 16 & 81,0 \\
\hline \multirow[t]{4}{*}{ WPM } & I re - culture & $1: 1$ & 2,0 & 3 & 0 \\
\hline & II re - culture & $1: 2$ & 2,9 & 5 & 0 \\
\hline & III re - culture & $1: 4$ & 3,8 & 7 & 10,0 \\
\hline & IV re - culture & $1: 5$ & 4,6 & 9 & 13,0 \\
\hline
\end{tabular}

As a result of re-culture of the experiments obtained, the newly formed tumors differed in length from the previous ones. Wonderful variety of pomegranate in MS control nutrient medium reproduction ratio 1: 2 in I-re-cultivation, horn length $2.4 \mathrm{~cm}$, leaves 5 pcs. The leaves were 12 pieces and the root rate was $0.7 \%$.

In the DKW nutrient medium, the reproduction rate of Wonderful Variety II was 1: 6, horn length was $11.6 \mathrm{~cm}$, leaves were 9, and rooting was $23.6 \%$. the number of leaves was 16 and the root rate was $81 \%$, compared to the control variant in IV re-cultivation, the growth rate of the micro-plant was 0.3 , the length of the horn was $6.7 \mathrm{~cm}$, the number of leaves was 4 and the root rate was $80.3 \%$ higher.

In WPM nutrient medium, the reproduction ratio of Wonderful variety in I culture was 1: 1, horn length was $2.0 \mathrm{~cm}$, leaves were 3 and did not take root, in IV culture culture, the reproduction rate was 1: 5 , horn length was $4.6 \mathrm{~cm}$, leaves were 9 and rooting was $13 \%$, compared to the control variant in IV re-cultivation, the growth rate of the micro-plant was 0.4 less, the horn length was less than $2.2 \mathrm{~cm}$, the leaves were less than 3 , and the root rate was $12.3 \%$ higher.

In vitro growth of Wonderful cultivar MS, DKW, MStak (improved by Murashige and Skoog) and WPM in nutrient media 2, 3, 3.5 and $4 \mathrm{mg} / 1$ IBA (indole 3 fatty acid) rooting, number and length of roots studied.

Rooting of the Wonderful variety of pomegranate took full rooting in 9 days under the influence of IBA $3.5 \mathrm{mg} / 1$ of growth medium in a controlled nutrient medium, the number of roots was 3.8 , the length of the roots was $3.8 \mathrm{~cm}$, the root rate was $49.8 \%$.

Wonderful variety under DKW nutrient medium $4 \mathrm{mg} / 1$ IBA took full root in 4 days, the number of roots was 3.3 , the root length was $2.8 \mathrm{~cm}$, the root rate was $40.3 \%$, the full root of the variety compared to the control variant. 2 days early to take, the number of tubers was 0.5 , the length of the tubers was $1.1 \mathrm{~cm}$, a low rate of rooting was observed by $3.7 \%$.

Table 4

Influence of different concentrations of IBA growth material on rooting of Wonderful variety of pomegranate propagated in different nutrient media, 2020-2021.

\begin{tabular}{|l|c|c|c|c|c|c|}
\hline \multirow{2}{*}{$\begin{array}{c}\text { Nutrient } \\
\text { environment }\end{array}$} & $\begin{array}{c}\text { IBA, } \\
\mathbf{m g} / \mathbf{l}\end{array}$ & $\begin{array}{c}\text { First rooting, } \\
\text { date }\end{array}$ & Full rooting, date & \multicolumn{2}{|c|}{ Roots } \\
\cline { 5 - 7 } & & & & $\begin{array}{c}\text { Number, } \\
\text { pcs }\end{array}$ & $\begin{array}{c}\text { length, cm } \\
\text { Take root, } \\
\%\end{array}$ \\
\hline \multirow{3}{*}{ MS control } & 2 & $18 / \mathrm{V}$ & $28 / \mathrm{V}$ & 3,3 & 3,2 & 24,0 \\
\cline { 2 - 7 } & 3 & $17 / \mathrm{V}$ & $26 / \mathrm{V}$ & 3,3 & 3,0 & 37,0 \\
\cline { 2 - 7 } & 3,5 & $16 / \mathrm{V}$ & $24 / \mathrm{V}$ & 3,8 & 3,8 & 49,8 \\
\cline { 2 - 7 } & 4 & $16 / \mathrm{V}$ & $25 / \mathrm{V}$ & 3,8 & 3,9 & 44,0 \\
\hline \multirow{2}{*}{$\mathrm{DKW}$} & 2 & $21 / \mathrm{V}$ & $2 / \mathrm{VI}$ & 1,0 & 0,6 & 7,5 \\
\cline { 2 - 7 } & 3 & $18 / \mathrm{V}$ & $24 / \mathrm{V}$ & 2,5 & 2,2 & 23,5 \\
\hline
\end{tabular}


SJIF Impact Factor 2021: 8.013| ISI I.F.Value:1.241| Journal DOI: 10.36713/epra2016 ISSN: 2455-7838(Online)

EPRA International Journal of Research and Development (IJRD)

Volume: 6 | Issue: 11 | November 2021

- Peer Reviewed Journal

\begin{tabular}{|l|c|c|c|c|c|c|}
\hline & 3,5 & $18 / \mathrm{V}$ & $24 / \mathrm{V}$ & 3,3 & 2,7 & 36,3 \\
\cline { 2 - 7 } & 4 & $17 / \mathrm{V}$ & $23 / \mathrm{V}$ & 3,3 & 2,8 & 40,3 \\
\hline \multirow{3}{*}{ MS $_{\text {tak }}$} & 2 & $16 / \mathrm{V}$ & $19 / \mathrm{V}$ & 3,3 & 2,8 & 28,3 \\
\cline { 2 - 7 } & 3 & $15 / \mathrm{V}$ & $18 / \mathrm{V}$ & 4,5 & 4,1 & 52,5 \\
\cline { 2 - 7 } & 3,5 & $15 / \mathrm{V}$ & $17 / \mathrm{V}$ & 4,5 & 4,3 & 57,8 \\
\cline { 2 - 7 } & 4 & $13 / \mathrm{V}$ & $16 / \mathrm{V}$ & 5,0 & 5,2 & 65,0 \\
\hline \multirow{4}{*}{$\mathrm{WPM}$} & 2 & $20 / \mathrm{V}$ & $1 / \mathrm{VI}$ & 1,8 & 1,9 & 3,3 \\
\cline { 2 - 7 } & 3 & $20 / \mathrm{V}$ & $28 / \mathrm{V}$ & 2,5 & 2,5 & 6,3 \\
\cline { 2 - 7 } & 3,5 & $19 / \mathrm{V}$ & $27 / \mathrm{V}$ & 2,0 & 2,7 & 10,0 \\
\cline { 2 - 7 } & 4 & $19 / \mathrm{V}$ & $26 / \mathrm{V}$ & 2,3 & 2,1 & 9,8 \\
\hline
\end{tabular}

Growing agent in $\mathrm{MS}_{\mathrm{tak}}$ nutrient medium 4 $\mathrm{mg} / 1$ Under the influence of IBA Wonderful variety takes full root in 4 days, the roots are 5.0, the root length is $5.2 \mathrm{~cm}$, the root rate is $65.0 \%$, the full rooting of the variety compared to the control variant Early 3 days, the number of roots was 1.2 , the length of the roots was $1.3 \mathrm{~cm}$, and a high rate of rooting was observed by $21 \%$.

Under the influence of $3.5 \mathrm{mg} / 1 \mathrm{IBA}$ in WPM nutrient medium, the Wonderful variety took full root in 8 days, the number of roots was 2.0 , the root length was $2.7 \mathrm{~cm}$, and the root rate was $10.0 \%$, compared to the control variant. 1 day early to take, the number of roots was 1.8 , the length of the roots was $1.1 \mathrm{~cm}$, a low rate of $39.8 \%$ in rooting was noted.

The highest root formation rate in the Wonderful variety was under the influence of $4 \mathrm{mg} / 1$ IBA in the MStak nutrient medium, with the root yield of the variety being $65.0 \%$. The most inefficient indicator of its rooting was that under the influence of $2 \mathrm{mg} / 1$ IBA in WPM nutrient medium, the variety took full root in 9 days, the number of roots was 1.8 , the root length was $1.9 \mathrm{~cm}$ and the root rate was $3.3 \%$.

\section{CONCLUSIONS}

The Wonderful variety of pomegranate was found to be the most effective sterilizer, with $78.3 \%$ of the buds surviving by sterilization for 10 minutes in a $1.0 \% \mathrm{NaOCl}$ solution. In the DKW nutrient medium, which was found to be the most effective for replanting the Wonderful variety four times, the micro-plant reproduction rate was $1: 12$, horn length $13.5 \mathrm{~cm}$, leaves 16, and rooting $81 \%$. The most effective germination and germination percentage for the Wonderful variety of pomegranate was under the influence of BAP-1.0 ml / 1 and $\mathrm{GA}_{3}-0.2 \mathrm{mg} / 1$ in the DKW nutrient medium, with a germination rate of $65.9 \%$. It was noted that the highest root formation rate in this variety was $4 \mathrm{mg} / 1$ IBA in MStak nutrient medium.

\section{REFERENCES}

1. S. Islamov, J.Ochildiev. The effect of auxin on the rooting of microclonal multiplication of pomegranate variety "Zubayda-667". Agriculture and water management of Uzbekistan. 2021; 7:33-34

2. Anvarova MA. Morpho - physiological features of the regeneration of potato genotypes in vitro: author. dis ... cand. biol. Sciences. Anvarova Mavlyuda Anvarovna. - Dushanbe. 1998; 24.

3. Butenko R.G. New directions in plant physiology. RG Butenko. -M .: Nauk. 1985; 411.

4. Kosumbekova, F.A. Features of the cell culture of actinidia (Actinidia chinesis Planch) and black currant Ribes nigrum L.) in vitro: author. dis. Cand. s.-kh. Sciences: 03.00.12. Kosumbekova, Fotima Anoyatbekovna. - Dushanbe. 2005; 17.

5. Saimnazarov Yu.B, Abduramanova $S$. Introduction and re-cultivation of weakly growing cherry Gisela-5 graft in vitro in different nutrient media. Agro ilm. Tashkent. 2020; 4 (67): 36-38. 